\title{
Implementasi Rally Coach Untuk Mengembangkan Keterampilan Berpikir Kritis Pada Pelajaran Matematika
}

\author{
Joko Krismanto Harianja \\ joko.harianja@outlook.co.id \\ Universitas Pelita Harapan
}

The Implementation Of Rally Coach To Develop Critical Thinking Skills In Mathematics Lesson

\begin{abstract}
Critical thinking skills need to be developed in learning activities because these skills are needed by students especially in solving problems both in everyday life and for the future. Based on research that has been done, students' critical thinking skills can be developed by implementing the rally coach learning model in mathematics learning activities. Rally coach is a cooperative learning model. From the research results obtained using descriptive research methods with a qualitative approach, students' critical thinking skills have increased significantly which indicates that the implementation of the rally coach learning model was declared successful. This study has been done using CAR (Class Action Research) method with 4 cycles. As part of the research, to find out an increase in accordance with expected, researchers designed a test instrument that has been tested for validity and reliability using the content validity ratio (CVR) method and the Cronbach Alpha formula. The results that have been obtained show in detail that the rally coach learning model provides an excellent contribution to improving students' critical thinking skills.
\end{abstract}

Keywords: Rally Coach, Critical Thinking Skills, Validity and Readibility Test, Instrument Designing, Cooperative Learning

\author{
Revised date: 12 Maret $2020 \quad$ Accepted date: 14 Mei 2020
}

\section{PENDAHULUAN}

Belajar adalah proses manusia untuk mencapai berbagai macam kompetensi, keterampilan, dan sikap (Herawati, 2018). Upaya untuk mencapai kecerdasan atau pengetahuan serta memenuhi kebutuhannya, memperoleh pengetahuan atau kecerdasan yang belum pernah dimiliki sebelumnya. Jadi dengan belajar manusia menjadi tahu, mengerti, memahami, dapat mengimplementasikan dan memiliki tentang sesuatu. Secara keseluruhan proses pendidikan di sekolah, kegiatan belajar mengajar adalah kegiatan yang paling dasar. Artinya sukses atau tidak pencapaian tujuan pendidikan tergantung pada proses pembelajaran yang dilakukan oleh siswa (Mirlanda, Nindiasari, \& Syamsuri, 2020).

Belajar pada dasarnya adalah kegiatan kompleks yang memberikan hasil dalam bentuk kemampuan. Hasil belajar adalah penguasaan terhadap suatu keterampilan, pengetahuan, sikap, dan nilai. Munculnya kemampuan ini adalah hasil dari stimulasi yang berasal dari lingkungan dan proses kognitif yang dilakukan oleh siswa (Mahmud, 2020). Belajar merupakan serangkaian proses kognitif yang mengubah sifat stimulasi lingkungan, melalui pemrosesan informasi, menjadi kemampuan baru.

Proses kognitif adalah aktivitas di dalam pikiran siswa yang meliputi menerima informasi, mengolah informasi, menyimpan informasi dan memanggil kembali informasi dari ingatan ketika dibutuhkan untuk digunakan selanjutnya (Fajriati \& Wijayanti, 2018). Terdapat hubungan yang erat antara proses kognitif dan pemecahan masalah. Dalam memecahkan masalah seseorang mengumpulkan informasi yang relevan, mengidentifikasi informasi, menganalisis informasi dan mengambil keputusan. Salah satu strategi dalam memecahkan masalah yang dihadapi siswa dapat dipengaruhi oleh kemampuan matematika sehingga perbedaan kemampuan matematika juga dapat mempengaruhi proses kognitif siswa (Fajriati \& Wijayanti, 2018).

Pemecahan masalah merupakan proses berpikir tingkat tinggi yang memerlukan proses berpikir yang kompleks termasuk di dalamnya adalah berpikir kritis. Berpikir kritis diperlukan dalam pemecahan masalah karena berpikir kritis memberikan arahan yang tepat dalam berpikir dan bekerja, 
serta membantu menemukan keterkaitan faktor yang satu dengan yang lain secara tepat (Firgula, Fayeldi, \& Farida, 2019).

Berdasarkan fakta yang terdapat di lapangan, masih terdapat banyak siswa kelas VII SMP salah satu sekolah swasta di kota Bogor memiliki kesulitan dalam memecahkan masalah khsususnya dalam pelajaran matematika. Hasil ujian kuartal pertama mata pelajaran matematika kelas VII tahun ajaran 2019/ 2020 masih begitu rendah dan tidak mencapai standar kelulusan. Adapun nilai standar kelulusan untuk mata pelajaran matematika adalah $65 \%$, sedangkan nilai rata-rata keseluruhan untuk mata pelajaran matematika kelas VII adalah sebesr $50,4 \%$.

Kondisi fakta di lapangan yang menunjukkan bahwa siswa sulit memecahkan masalah matematika mengindikasikan bahwa keterampilan berpikir kritis siswa kelas VII masih sangat rendah dan perlu dikembangkan. Oleh karena itu penelitian ini dilakukan sebagai tindakan inovasi dalam strategi pembelajaran untuk meningkatkan keterampilan berpikir kritis siswa dengan mengimplementasikan model pembelajaran kooperatif Rally Coach.

\section{KAJIAN PUSTAKA}

Pendidikan merupakan proses interaksi antara pendidik dan peserta didik baik secara formal, nonformal maupun informal. Pada pendidikan formal, pembelajaran memegang peranan penting dalam membentuk siswa sebagai sumber daya manusia yang unggul untuk dapat berpikir dan bersikap kritis, logis, analisis,sistematis, kritis, dan kreatif dalam menyelesaikan permasalahan dengan dibekali dengan kemampuan berpikir yang berhubungan dengan kegiatan belajar siswa dan mampu mengaplikasikan dalam kehidupan sehari-hari (Chotimah, Ramdhani, Bernard, \& Akbar, 2018)

Salah satu tujuan pendidikan Abad 21 yaitu mengembangkan keterampilan berpikir siswa, salah satunya keterampilan berpikir kritis. Berpikir kritis adalah kemampuan berpikir reflektif yang berfokus pada pola pengambilan keputusan tentang apa yang harus diyakini, harus dilakukan dan dapat dipertanggung jawabkan (Susilawati, Samsudin, \& Siahaan, 2020). Dalam memutuskan apa yang akan dipercaya dan apa yang akan dilakukan, diperlukan informasi yang reliabel dan pemahaman terhadap topik yang sedang dibahasa atau didiskusikan. Berdasarkan hal tersebut seseorang dapat mengambil keputusan yang reliabel (Abdullah, 2013). Keputusan berdasarkan keyakinan merupakan hal sangat penting. Suatu kunci dalam memutuskan suatu keyakinan sering merupakan sebuah argumen. Seseorang yang memiliki keterampilan berpikir kritis mampu mengambil keputusan mengenai apa yang akan diyakini dan apa yang akan dilakukan berdasarkan informasi yang dapat dipercaya dan pemahaman terhadap topik yang dihadapi (Abdullah, 2013).

Keterampilan berpikir kritis merupakan tujuan pembelajaran modern. Pembelajaran sendiri merupakan kegiatan belajar dan mengajar di sebuah konteks ruang dan waktu yang memanfaatkan metode tertentu sehingga menghasilkan perubahan pemikiran, sikap, pengembangan keterampilan dan pengetahuan, sesuai target yang ingin dicapai (Setyaningtyas et al., 2019).

Keterampilan berpikir kritis sangat diperlukan karena seseorang yang berpikir kritis mampu berpikir logis, menjawab permasalahan dengan baik dan dapat mengambil keputusan rasional tentang apa yang harus dilakukan atau apa yang diyakini. Berpikir kritis adalah keterampilan berpikir tingkat tinggi yang berpotensi meningkatkan daya analitis kritis peserta didik. Oleh karena itu, mengembangkan keterampilan berpikir kritis peserta didik dalam pembelajaran menjadi upaya untuk meningkatkan hasil belajar peserta didik (Susilawati et al., 2020).

Berpikir kritis merupakan keterampilan yang penting bagi siswa, sehingga berpikir kritis hendaknya menjadi salah satu aktivitas yang harus dikembangkan dan diajarkan di setiap mata pelajaran, karena kemampuan berpikir kritis bukan bawaan sejak lahir dan tidak berkembang secara alami (Cahyono, 2017). Kemampuan berpikir kritis adalah potensi intelektual yang dapat dikembangkan melalui proses pembelajaran. Berpikir kritis merupakan suatu keterampilan yang harus diajarkan pada siswa melalui matematika, ilmu pengetahuan alam atau disiplin yang lain untuk mempersiapkan siswa agar berhasil dalam kehidupan (Tresnawati, Hidayat, \& Rohaeti, 2017). Sedangkan yang bertanggung jawab untuk mengembangkan dan mengajarkan salah satunya adalah guru karena seorang guru memiliki keleluasaan untuk membuat rancangan pembelajaran sebelum proses pembelajaran dilakukan. Ketrampilan berpikir kritis dapat dimiliki oleh seorang siswa jika siswa tersebut secara konsisten dilatih baik melalui diskusi terarah maupun dengan difasilitasi oleh seorang instruktur (Cahyono, 2017). 
Hasil belajar yang berupa kemampuan akademik, sosial, dan karakter tidak lepas dari peran keterampilan kognitif siswa, yang membuat mereka berpikir dalam berperilaku dan membuat keputusan dalam melakukan segala hal. Hampir tidak ada suatu hal dilakukan manusia tanpa berpikir, apalagi keterampilan ini sangat diperlukan untuk kelangsungan hidup dan menunjang kesuksesan di masa depan. Oleh karena itu, guru perlu mengembangkan keterampilan berpikir peserta didiknya, yang sangat penting dilatih sejak dini, sehingga peserta didik secara mandiri dapat berpikir kritis (Setyaningtyas et al., 2019)

Salah satu aspek penting dalam pembelajaran matematika adalah keterampilan berpikir kritis. Materi dalam pembelajaran matematika dimengerti dengan cara berpikir kritis, dan salah satu cara melatih berpikir kritis adalah melalui belajar matematika, sehingga materi dalam matematika dan keterampilan berpikir kritis menjadi dua hal yang tidak bisa dipisahkan (Danaryanti \& Lestari, 2018). Setiap proses pembelajaran matematika merupakan aktivitas yang membantu siswa dalam pengembangan analitis, penalaran kritis, pemecahan masalah, dan keterampilan komunikasi. Berpikir kritis dalam matematika adalah berpikir dalam hal menguji, mempertanyakan, menghubungkan, mengevaluasi semua aspek yang ada dalam suatu situasi maupun dalam suatu masalah. Berdasarkan pernyataan ini makaa dapat dikatakan bahwa berpikir kritis adalah berpikir secara beralasan dan reflektif dengan menekankan pada pembuatan keputusan tentang apa yang harus dipercayai atau dilakukan (Zetriuslita, Ariawan, \& Nufus, 2016).

Adapun indikator keterampilan berpikir kritis, yaitu : (i) menentukan konsep yang digunakan dalam menyelesaikan masalah, (ii) merumuskan suatu tindakan dalam menyelesaikan masalah, (iii) memberikan argument atau alasan dala menjawab dan menyelesaikan masalah dan (iv) melakukan evaluasi dalam menyelesaikan masalah (Danaryanti \& Lestari, 2018).

Mengajarkan keterampilan berpikir kritis dalam pembelajaran matematika sangat penting bagi siswa karena dengan keterampilan ini siswa mampu bersikap rasional dan memilih alternatif pilihan yang terbaik bagi dirinya. Selain itu, menanamkan kebiasaan berpikir kritis bagi siswa perlu dilakukan agar mereka dapat mencermati berbagai persoalan yang terjadi dalam kehidupan sehari-hari (Novtiar \& Aripin, 2017)

Melalui mengajarkan keterampilan berpikir kritis dalam pembelajaran matematika kepada siswa, diharapkan siswa mampu mengembangkan pola berpikir mereka agar pada masa yang mendatang, sebagai generasi muda bangsa, mereka mampu bersaing di tingkat global (Novtiar \& Aripin, 2017). Oleh karena itu, setiap sekolah perlu menjadikan pengajaran keterampilan berpikir kritis sebagai sebuah tradisi untuk mengembangkan proses kognitif siswa. Sekolah perlu mendorong setiap guru untuk mengajarkan keterampilan berpikir krisis tidak hanya pada pembelajaran matematika, tetapi juga pada mata pelajaran lainnya untuk mendorong siswa memunculkan ide-ide baru atau memikirkan ulang kesimpulan-kesimpulan yang sudah ada (Haeruman, Rahayu, \& Ambarwati, 2017).

Berpikir kritis tidak muncul begitu saja. Berpikir kristis membutuhkan stimulus yang tepat untuk dapat hadir, khususnya di dalam kelas. Pembelajaran yang baik, dimulai dari masalah. Masalah bukanlah masalah yang biasa digambarkan banyak orang sebagai sebuah sebuah keadaan yang menyusahkan. Masalah yang dimaksud adalah segala keadaan yang menimbulkan pertanyaan dalam diri siswa yang kemudian menjadi obyek pembahasan dalam pembelajaran. Dalam hal ini, maka guru dan siswa sama-sama mengarahkan fokus pembelajaran untuk membahas masalah tersebut. Siswa tidak dipandang sebagai obyek dan guru sebagai subyek. Siswa dan guru menjadi rekan. Kondis ini menstimulus siswa untuk berpikir. Siswa mengambil masalah tersebut menjadi hak miliknya dan kemudian melibatkan banyak dimensi berpikirnya (Purba, 2015).

Untuk mengembangkan keterampilan berpikir kritis siswa, guru harus memiliki inovasi dalam strategi pembelajaran. Pemilihan model kooperatif dalam kegiatan pemebelajaran matematika merupakan salah satu usaha untuk meningkatkan keterampilan berpikir kritis dengan menciptakan pembelajaran yang menarik dan menyenangkan(Fardilla, Soetjipto, \& Suardana, 2020). Pembelajaran kooperatif merupakan pembelajaran yang dilakukan dengan siswa bekerjasama dan bertanggung jawab atas pembelajaran orang lain sebagaiman pembelajaran mereka sendiri. Permasalahan terkait keterampilan berpikir kritis dalam pembelajaran dapat diatasi dengan menerapkan model pembelajaran kooperatif (Kagan \& Kagan, 2009).

Salah satu strategi pembelajaran yang dapat digunakan dalam penelitian ini adalah dengan mengimplementasikan model pembelajaran Rally Coach. Rally coach merupakan salah satu strategi pembelajaran kooperatif (cooperative learning) yang sangat tepat untuk diimplementasikan dalam 
pelajaran matematika khususnya ketika sedang menjawab pertanyaan (Harianja, 2019). Strategi ini mendorong siswa untuk saling membantu satu dengan yang lain dalam menjawab pertanyaan, siswa diharuskan untuk saling berkomunikasi dan memperhatikan dengan teliti proses yang dilakukan ketika sedang menjawab pertanyaan. Ketika siswa sedang menjawab persoalan, tidak lain membutuhkan proses berpikir yang sedemikian rupa sehingga dapat dituangkan dalam tulisan dan kemudian dikomunikasikan kepada orang lain.

Saat proses kegiatan pembelajaran sedang berlangsung dengan menggunakan strategi Rally Coach, siswa mendapat manfaat langsung untuk belajar mencurahkan dalam mengembangkan kemampuan kemampuan berpikirnya secara kritis, menuangkannya di dalam tulisan, memahami sudut pandang orang lain, meningkatkan kemampuan pemecahan masalah dan memberikan umpan balik (Eggen, 2012). Dengan kata lain, proses pembelajaran ini membantu orang lain, belajar untuk menghargai orang lain, dan belajar untuk menerima kritik konstruktif.

\section{METODE PENELITIAN}

Artikel ini merupakan hasil observasi atau pengamatan terhadap implementasi model pembelajaran kooperatif dengan strategi Rally Coach untuk meningkatkan keterampilan berpikir kritis siswa dalam pembelajaran matematika dengan topik bahasan persamaan dan pertidaksamaan linier sederhana dengan satu peubah. Adapun metode penelitian yang digunakan adalah penelitian tindakan kelas (PTK) dengan menerapkan model spiral Kemmis dan Mctaggart. Dalam penelitian tindakan ini, peneliti melakukan sesuatu tindakan treatment yang secara khusus diamati terus menerus, dilihat kelebihan maupun kekurangannya, kemudian diadakan pengubahan terkontrol sampai pada upaya maksimal dalam bentuk tindakan yang paling benar. Model pembelajaran Rally Coach dilakukan dalam empat siklus. Hasil penelitian yang diperoleh berasal dari analisa yang mendalam terhadap keterampilan berpikir kritis siswa pada persoalan matematis yang telah diujikan terlebih dahulu. Ada empat tahapan yang harus dikerjakan dalam penelitian tindakan kelas menggunakan model ini, yaitu tahap perencanaan ( lan), tahap tindakan (act), tahap pengamatan (observe) dan tahap refleksi (reflect) (Harianja, 2019).

Penelitian ini dilakukan di salah satu sekolah menengah pertama (SMP) swasta di Jawa Barat yang menggunakan kurikulum satuan pendidikan kerjasama (SPK). Pada penelitian ini yang menjadi subjek penelitian adalah siswa kelas 7 yang terdiri dari 19 orang dengan rincian 8 orang siswa laki-laki dan 11 orang siswa perempuan. Instrumen dalam penelitian ini adalah soal tes yang dirancang oleh peneliti. Tes ini dilakukan untuk mengetahui seberapa besar tingkat keterampilan berpikir kritis siswa dalam pelajaran matematika setelah siklus keempat selesai dilakukan. Setiap butir soal yang diberikan memuat setiap indikator kemampuan berpikir secara kritis dengan jumlah soal sebanyak delapan pertanyaan yang merupakan pertanyaan uraian dan soal cerita.

Instrumen yang telah dirancang dievaluasi kesahihannya dengan uji validitas yaitu untuk mengukur tingkat validitas soal pada instrumen tes dengan metode content validity ratio (CVR). Uji reliabilitas pada instrumen juga diperlukan untuk mengevaluasi tingkat konsistensis setiap butir soal. Uji reliabilitas setiap butir soal pada instrumen menggunakan rumus Alpha Cronbach. Data yang diperoleh dianalisa menggunakan perhitungan statistik deskriptif.

\section{HASIL PENELITIAN DAN PEMBAHASAN}

Sebelum memberikan instrumen tes keterampilan berpikir kritis kepada siswa, terlebih dahulu instrument tes tersebut diuji validitasnya dengan menggunakan metode CVR. Dalam hal ini peneliti meminta bantuan para guru lain yang mengajar matematika untuk berperan sebagai panelis atau pakar yang menguji setiap butir soal pada instrument tes yang digunakan untuk menganalisa keterampilan berpikir kritis siswa. Ada empat orang guru matematika yang menjadi pakar dalam hal ini. Para panelis ini adalah para guru matematika yang telah memiliki pengalaman mengajar yang sudah begitu lama dan sangat berpengamalan dalam merancang maupun menguji berbagai jenis instrumen tes.

Jumlah butir soal yang terdapat pada intumen tes adalah sebanyak 12 butir soal yang merupakan soal uraian yang memuat 4 indikator keterampilan berpikir kritis. Dari 12 butir soal pada instrument, masing-masing indikator diwakili oleh tiga butir pertanyaan. Hasil pengujian validitas pada instrumen tes dengan menggunakan metode CVR menunjukkan bahwa seluruh soal yang telah dirancang adalah valid. Secara spesifik hasil pengujian menunjukkan kevalidan instrument berada pada nilai 0.99. Setelah 
melalukan uji validitas terhadap instrument soal, sebagai tahap berikutnya dilakukan uji reabilitas. Uji reabilitas yang telah dilakukan dengan menggunakan rumus Alpha Conbach terhadap instrumen soal menghasilkan koefisien reliabilitas yang cukup yaitu sebesar 0.75. Dalam bukunya (Sujarweni, 2004), Sujarweni mennyatakan bahwa untuk penelitian dengan menggunakan uji reliabilitas Alpha Cronbach, pengambilan keputusan dengan mengambil nilai Alpha Cronbach > 0.60 maka insturmen dinyatakan reliable atau konsisten. Hasil uji reabilitas pada instrumen soal yang dirancang menyatakan bahwa instrumen soal tersebut sangat realibel untuk digunakan dalam penelitian.

Penelitian ini dilaksanakan untuk meningkatkan keterampilan berpikir kritis siswa dengan mengimplementasikan model pembelajaran Rally Coach pada pembelajaran materi persamaan dan pertidaksamaan linear dengan satu peubah. Dalam pelaksanaannya, implementasi model pembelajaran ini dimulai dengan memberikan soal kepada siswa untuk dijawab secara bergiliran di dalam satu kelompok kecil yang terdiri dari dua orang siswa.

Di dalam kegitan pembelajaran ini, siswa di dalam kelompok secara bergantian menjawab soalsoal yang diberikan dengan acuan, ketika salah seorang siswa (siswa A) sedang menjawab soal. Siswa lain (siswa B) di dalam kelompok kecil tersebut mengamati dengan teliti, mendengarkan serta memeriksa dengan seksama setiap proses yang dituliskan oleh siswa A. Ketika sedang menjawab soal siswa A harus mengkomunikasikan secara verbal setiap langkah atau proses yang dituliskannya secara jelas. Selain berperan sebagai siswa yang mengamati, siswa B memiliki kesempatan untuk membantu siswa A apabila menemukan kesulitan dalam menjawab soal atau menemukan langkah yang salah ketika menjawab soal.

Penerapan model pembelajaran Rally Coach ini dilakukan dalam empat siklus. Dari siklus pertama sampai kepada siklus keempat, dilakukan perbaikan demi perbaikan untuk mencapai keberhasilan yang sesuai dengan tujuan penelitian, yaitu untuk meningkatkan keterampilan berpikir siswa. Perbaikan ini juga dilakukan untuk memperoleh hasil penelitian yang tepat sebagai jawaban atas masalah yang terjadi dilapangan. Hasil pengamatan yang diperoleh pada setiap siklus dijadikan bahan untuk didiskusikan dan dievaluasi bersama dengan rekan guru matematika yang lain.

Pada akhir siklus keempat, hasil pengamatan menunjukkan bahwa model pembelajaran Rally Coach telah diterapkan dengan baik. Hal ini juga didukung oleh setiap catatan yang diberikan oleh guru matematika lain sebagai pengamat pelaksanaan model pembelajaran Rally Coach. Guru yang berperean sebagai fasilitator meningkatkan perannya untuk melaksanakan perbaikan pada tahap II, II dan IV. Dalam kegiatan pembelajaran siswa mampu mengikuti setiap langkah-langkah pada model pembelajaran Rally Coach khususnya dalam memecahkan masalah. Siswa mampu menyelesaikan persoalan matematika yang diberikan dengan baik dan saling menkomunikasikan setiap gagasan serta langkah-langkah penyelesaian dengan tepat.

Untuk mengetahui peningkatan keterampilan berpikir kristis siswa, guru memberikan tes setelah siklus keempat selesai dilaksanakan. Soal tes yang diberikan sesuai dengan soal yang sudah dirancang sebelumnya menurut indikator penilaian keterampilan berpikir kritis siswa.

Adapun ringkasan hasil analisa serta evaluasi data tes keterampilan berpikir kritis siswa setelah siklus keempat dilaksanakan adalah sebagai berikut:

Tabel 1. Deskripsi Statistik Tes Keterampilan Berpikir Sebelum dan Sesudah Treatment

\begin{tabular}{ccc}
\hline Data Tes & Sebelum Rally Coach & Setelah Rally Coach \\
\cline { 2 - 3 } & Nilai & Nilai \\
\hline Nilai minimum & 35 & 55 \\
\hline Nilai maksimum & 90 & 95 \\
\hline Rata-rata $($ mean $)$ & 69.58 & 76.88 \\
\hline Nilai tengah $($ median$)$ & 72.5 & 77.5 \\
\hline Modus $($ mode $)$ & 55 & 85 \\
\hline Varian $\left(\sigma^{2}\right)$ & 479.36 & 178.12 \\
\hline Standar deviasi $(\sigma)$ & 21.89 & 14.34 \\
\hline
\end{tabular}

Berdasarkan informasi pada tabel 1 di atas dapat diketahui bahwa perhitungan data secara statistik menunjukkan bahwa hasil penilaian keterampilan berpikir kritis siswa pada pelajaran matematika kelas 7 mengalami peningkatan yang cukup signifikan. Peningkatan ini dipengaruhi oleh 
implementasi model pembelajaran rally coach yang secara terus menerus diterapkan di dalam kegiatan pembelajaran.

Dari perhitungan diperoleh pada tabel 1 di atas nilai rata-rata mengalami kenaikan dari 69.68 menjadi 76.88. Nilai modus yaitu nilai yang paling banyak muncul sebagai hasil pembelajaran siswa yang melalui tes juga mengalami perubahan. Sebelum dilakukan model pembelajaran rally coach, diperoleh nilai paling banyak yang diperoleh oleh siswa adalah 55. Namun, setelah menggunakan model pembelajaran rally coach, nilai yang paling banyak diperoleh oleh siswa adalah 85 .

Dari perhitungan secara statistik yang telah diperoleh diketahui bahwa standar deviasi yang diperoleh setelah menggunakan model pembelajaran rally coach sebesar 14.34. Standar deviasi ini jauh berbeda dari standard deviasi sebelum dilakukannya model pembelajaran rally coach. Standar deviasi yang diperoleh setelah melakukan model pembelajaran rally coach menunjukkan bahwa nilai siswa secara individu tidak begitu jauh dari nilai rata-rata yand diperoleh.

Secara keseluruhan, hasil tes keterampilan berpikir kritis siswa dapat dilihat pada tabel 2. Tabel 2 memberikan informasi secara lengkap hasil tes keterampilan berpikir kritis pada pembelajaran matematika kelas 7 dengan materi simple linear equations and simple inequalities dengan menggunakan model pembelajaran rally coach. Hasil yang ditunjukkan pada tabel 2 adalah berupa persentase keterampilan berpikir kritis siswa per indikator.

Tabel 2. Persentase Keterampilan Berpikir Siswa per Indikator

\begin{tabular}{lcccc}
\hline \multicolumn{1}{c}{ Indikator } & $\begin{array}{c}\text { Rata-rata Skor } \\
\text { Indikator }\end{array}$ & $\begin{array}{c}\text { Skor Ideal } \\
\text { Indikator }\end{array}$ & $\begin{array}{c}\text { Presentase } \\
\text { per Indikator }\end{array}$ & Kategori \\
\hline Menentukan konsep & 7.12 & 8 & $89.0 \%$ & Tinggi \\
\hline Merumuskan masalah & 6.08 & 8 & $76.0 \%$ & Tinggi \\
\hline Memberikan argumen & 5.76 & 8 & $72.0 \%$ & Sedang \\
\hline Mengevaluasi & 3.25 & 4 & $81.3 \%$ & Tinggi \\
\hline \multicolumn{2}{c}{ Rata-rata Total } & & $79.58 \%$ & \\
\hline
\end{tabular}

Tabel 2 di atas menunjukkan dengan jelas persentase angka capaian keterampilan berpikir siswa secara umum dengan rata-rata total sebesar $79.58 \%$. Dalam hal ini dapat diketahui dengan jelas bahwa indikator 1 adalah indikator dengan nilai skor rata-rata tertinggi sebesar $89 \%$. Hal ini menyatakan bahwa siswa mampu menentukan konsep yang tepat dalam menyelesaikan persoalan yang diberikan pada insturmen soal tes yang telah dirancang sebelumnya. Dalam tahapan berikutnya yaitu tahap perumusan masalah yang pada indikator 2 merupakan bagian yang penting dan diharapkan kepada semua siswa dapat mencaapai skor yang tinggi. Indikator 2 ini berhubungan dengan bagaimana siswa merumuskan masalah pada soal yang diberikan dan melalui perumusan tersebut dapat menyelesaikan masalah dengan baik dan benar. Angka capaian pada indikator 2 ini juga sangat baik, yaitu sebesar $76 \%$. Hal ini menyatakan bahwa siswa memeliki keterampilan atau kemampuan yang baik dalam merumuskan masalah yang kemudian diarahkan kepada pemecahan masalah. Indikator berikutnya yaitu indikator 3, yaitu memberikan argument dalam menyelesaikan suatu masalah. Angka capaian pada indikator ini adalah $72.0 \%$. Indikator 4 merupakan tahapan evaluasi siswa terhadap masalah yang telah mereka pecahkan dan selesaikan dengan angkai capaian 81.3\%. Adapun indikator 3 dan indikator 4 menyatakan bahwa siswa telah memiliki kemampuan yang baik alam memberikan argumen dan evaluasi terhadap apa yang telah mereka kerjakan pada tahapan-tahapan sebelumnya.

Dilihat dari data yang dipaparkan pada tabel 3 di atas juga keterampilan berpikir kritis siswa per indikator terserbar dalam 3 kategori tingkatan, yaitu tinggi, sedang dan rendah. Indikator menentukan konsep, indikator merumuskan masalah dan indikator mengevaluasi berada pada kategori tinggi. Hal ini terjadi karena pada saat kegiatan pembelajaran di dalam kelas menggunakan model pembelajaran Rallycoach, setiap siswa sudah terlatih untuk menyelesaikan soal-soal yang diberikan dari tingkat kesulitan yang berbeda-beda. Melalui latihan-latihan soal yang diberikan guru pada saat pembelajaran dengan menggunakan model Rally Coach, siswa menjadi terlatih untuk melalui fase klarifikasi masalah, merumuskan masalah dengan mengumpulkan serta menuliskan seluruh informasi yang terdapat pada soal. Indikator memberikan argumen berada pada kategori sedang, karena pada saat pembelajaran siswa sangat terlatih dalam menyelesaikan masalah namun masih terlihat keengganan saat mengkomunikasinnya dengan baik kepada teman di dalam kelompok, khususnya apabila terjadi kesalahan-kesalahan kecil. 
Hasil yang telah diperoleh ini sesuai dengan penelitian yang telah dilakukan sebelumnya oleh peneliti lain dengan mengimplementasikan model pembelajaran Problem Based Learning (PBL) untuk meningkatkan ketempilan berpikir kritis dalam pelajaran teknik jaringan komputer. Hasil penelitian menggunakan PBL menunjukkan bahwa implementasi PBL berhasil meningkatkan keterampilan berpikir siswa dapat dilihat ketika siwa mampu menyelesaikan maslaah melalui tahapan-tahapan seperti memfokuskan kepada masalah yang diberikan, melakukan riset sederhana untuk memahami masalah lebih jelas lagi, melakukan investigasi terhadap masalah, menyajikan tahapan penyelesaian, menganalisis dan mengevaluasikan proses pemecahan masalah (Nafiah \& Suyanto, 2014).

Tabel 3. Distribusi Frekuensi Keterampilan Bepikir Kritis Siswa
\begin{tabular}{lccc}
\multicolumn{4}{c}{ Secara Keseluruhan } \\
\hline No. & Frekuensi & Persentase & Kategori \\
\hline 1. & 9 & $47.4 \%$ & Tinggi \\
\hline 2. & 8 & $42.1 \%$ & Sedang \\
\hline 3. & 2 & $10.5 \%$ & Rendah \\
\hline
\end{tabular}

Hasil yang diperoleh dari tes setelah siklus keempat kemudian disimpulkan ke dalam bentuk katekoti tingkat keterampilan berpikir siswa tinggi, sedang dan rendah. Dari tabel 3 di atas dapat dilihat bahwa rata-rata siswa kelas 7 berada pada kategori keterampilan berpikir kritis tinggi dengan presentase $47.4 \%$. Persentase siswa dengan kategori keterampilan berpikir kritis sedang dan $10 . \%$ berada pada kategori keterampilan berpikir kritis rendah. Tidak begitu banyak siswa yang berada pada kategori keterampilan berpikir kritis rendah. Hal ini terjadi kafrena siswa kelas 7 sudah terbiasa dengan model pembelajaran rally coach khususnya pada saat sedang memecahkan dan menyelesaikan persoalan matematika. Siswa sudah terlatih untuk memecahkan berbagai jenis persoalan matematika dengan berbagai tingkat kesulitan yang berbeda.

Pada penelitian dapat dilihat bahwa siswa dengan keterampilan berpikir kritis tinggi mampu memenuhi seluruh kriteria yang terdapat pada indikator keterampilan berpikir kritis. Siswa yang berada pada kategori keterampilan berpikir kritis tinggi mampu memecahkan dan menyelesaikan soal-soal yang diberikan pada instrumen dengan baik dengan menentukan konsep yang tepat dalam menyelesaikan masalah, membuat perumusan masalah yang tepat, memberikan argumen dan mengevaluasi hasil akhir yang diperoleh pada saat memecahkan masalah. Siswa yang berada dalam kategori keterampilan berpikir kritis sedang hanya mampu memenuhi indikator menentukan dan merumuskan masalah namun kurang mampu dalam memenuhi indikator memberikan argumen dan mengevaluasi. Sedangkan siswa yang berada dalam kategori keterampilan berpikir kritis rendah kurang mampu memenuhi indikator menentukan konsep dalam menyelesaikan masalah, merumuskan masalah, memberikan argumen dan mengevaluasi.

\section{SIMPULAN DAN SARAN}

Keterampilan berpikir kritis pada siswa sangat diperlukan dan harus dikembangkan. Keterampilan berpikir kritis sangat diperlukan untuk menyelesaikan atau memecahkan suatu masalah yang timbul baik dalam kehidupan sehari-hari maupun untuk masalah yang timbul pada masa mendatamg. Salah satu model pembelajaran yang dapat digunakan dalam kegiatan pembelajaran matematika untuk meningkatkan keterampilan berpikir kritis pada siswa adalah model pembelaran Rally Coach. Rally coach menjadi salah satu model pembelajaran yang sangat tepat untuk meningkatkan dan mengembangkan keterampilan berpikir kritis. Model pembelajaran Rally Coach mendukung siswa untuk bekerjasama dengan siswa lain dalam menyelesaikan suatu permasalahan dengan mengandalkan proses berpikir yang tepat dalam memecahkan masalah serta kemampuan untuk berkomunikasi dengan baik. Model pembelajaran Rally Coach dapat merangsang aspek-aspek penting dalam berpikir kritis seperti menganalisis, menentukan pemilihan konsep yang tepat, merumuskan masalah, mengkomunikasikan proses penyelesaian atau pemecahan masalah dan mengevaluasi hasil akhir pemecahan masalah.

Penerapan model pembelajaran Rally Coach pada kegiatan pembelajaran matematika dengan materi simple linear equation and linear inequalities dapat meningkatkan keterampilan berpikir kritis siswa kelas 7 tahun pelajaran 2019/2020. Peningkatan keterampilan berpikir kritis ini dapat dilihat tercapainya setiap indikator keterampilan berpikir kritis melalui tes yang diberikan setelah siklus 
keempat. Hasil tes siswa akhir yang telah diperoleh menunjukkan adanya peningkatan yang cukup signifikan pada nilai akademik siswa yang merupakan bukti hasil implementasi model pembelajaran Rally Coach dalam meningkatkan keterampilan berpikir kritis siswa.

Dilihat dari cara siswa menjawab atau memecahkan masalah yang diberikan secara tertulis juga menunjukkan hasil proses berpikir siswa dan interpretasi matematis yang baik. Hal ini menunjukkan bahwa keterampilan berpikir kristis siswa kelas VII telah mengalami peningkatan. Sebagai saran untuk penelitian berikutnya, diharapkan untuk melakukan penelitian lebih lanjut dalam menggunakan model pembelajaran Rally Coach untuk meningkatkan keterampilan atau kemampuan lain seperti komunikasi matematis, berpikir secara sistematis, berpikir secara analisis dan kemampuan berpikir tingkat tinggi. Diharapkan juga model pembelajaran Rally Coach dapat digunakan pada penelitian-penelitian dengan pembelajaran lain di luar seperti fisika, biologi, kimia atau ilmu-ilmu sosial.

\section{DAFTAR PUSTAKA}

Abdullah, I. H. (2013). Berpikir Kritis Matematik. Jurnal Matematika Dan Pendidikan Matematika, 2(1), 66-75. Retrieved from http://www.ejournal.unkhair.ac.id/index.php/deltapi/article/view/100

Cahyono, B. (2017). Analisis Ketrampilan Berfikir Kritis Dalam Memecahkan Masalah Ditinjau Perbedaan Gender. Aksioma, 8(1), 50. https://doi.org/10.26877/aks.v8i1.1510

Chotimah, S., Ramdhani, A., Bernard, M., \& Akbar, P. A. (2018). Pengaruh Pendekatan ModelEliciting Activities Terhadap Kemampuan Berpikir Kritis Matematik Siswa SMP Negeri di Kota Cimahi. Jurnal on Education, 2(1), 78-77. https://doi.org/10.22460/p2m.v2i1p40-45.162

Danaryanti, A., \& Lestari, A. T. (2018). Analisis Kemampuan Berpikir Kritis Dalam Matematika Mengacu Pada Watson-Glaser Critical Thinking Appraisal Pada Siswa Kelas Viii Smp Negeri Di Banjarmasin Tengah Tahun Pelajaran 2016/2017. EDU-MAT: Jurnal Pendidikan Matematika, 5(2), 116-126. https://doi.org/10.20527/edumat.v5i2.4631

Fajriati, M., \& Wijayanti, P. (2018). Proses Kognitif Siswa Dalam Memecahkan Masalah Matematika Ditinjau Dari Kemampuan Matematika. Jurnal Ilmiah Pendidikan Matematika, 7(3), 21-29. Retrieved from https://jurnalmahasiswa.unesa.ac.id/index.php/mathedunesa/article/view/25554/23429

Fardilla, Y., Soetjipto, B. E., \& Suardana, I. M. (2020). Penerapan Model Modified Find Someone Who dan Quiz-Quiz Trade untuk Meningkatkan Keterampilan Sosial Siswa Sekolah Dasar. Jurnal Pendidikan: Teori, Penelitian Dan Pengembangan, 5(1), 52-56.

Firgula, M., Fayeldi, T., \& Farida, N. (2019). Analisis Berpikir Kritis Peserta Didik Dalam Menyelesaikan Soal Cerita Statistika Kelas X. Jurnal MathEduNesa, 2, 285-295.

Haeruman, L. D., Rahayu, W., \& Ambarwati, L. (2017). Pengaruh Model Discovery Learning Terhadap Peningkatan Kemampuan Berpikir Kritis Matematis Dan Self-Confidence Ditinjau Dari Kemampuan Awal Matematis Siswa Sma Di Bogor Timur. Jurnal Penelitian Dan Pembelajaran Matematika, 10(2), 157-168. https://doi.org/10.30870/jppm.v10i2.2040

Harianja, J. K. (2019). Implementasi Cooperative Learning dengan Menggunakan Strategi Rally Coach untuk Mengembangkan Keterampilan Komunikasi Matematis. Dwija Cendekia Jurnal Riset Pedgogik, 3(2), 175-182.

Herawati. (2018). Memahami Proses Belajar Anak. Jurnal Pendidikan Anak Bunayya, 4(1), 27-48.

Mahmud, T. (2020). Perbedaan Hasil Belajar Materi Teks Eksplanasi Dengan Menggunakan Model Pembelajaran Kooperatif Tipe Broken Heart dan Pembelajaran Konvensional Pada Siswa kelas VIII SMP Negeri Banda Aceh. Jurnal Metamorfosa, 8(1), 123-129.

Mirlanda, E. P., Nindiasari, H., \& Syamsuri. (2020). Pengaruh Pembelajaran Flipped Classroom Terhadap Kemampuan Penalaran Matematis Ditinjau Dar Gaya Belajar Kognitif Siswa. Prima: Jurnal Pendidkan Matematika, 4(1), 11-21. 
Implementasi Rally Coach Untuk Mengembangkan Keterampilan Berpikir Kritis Pada Pelajaran Matematika (Joko Krismanto Harianja)

Nafiah, Y. N., \& Suyanto, W. (2014). Penerapan Model Problem-Based Learning untuk Meningkatkan Keterampilan Berpikir Kritis dan Hasil Belajar Siswa. Jurnal Pendidikan Vokasi, 4(1), 125143. https://doi.org/10.21831/jpv.v4i1.2540

Novtiar, C., \& Aripin, U. (2017). Meningkatkan Kemampuan Berpikir Kritis Matematis Dan Kepercayaan Diri Siswa SMP Melalui Pendekatan Open Ended. Prisma, 6(2), 119-131. https://doi.org/10.35194/jp.v6i2.122

Purba, R. T. (2015). Sebuah Tinjauan Mengenai Stimulus Berpikir Kritis. Scholaria: Jurnal Pendidikan Dan Kebudayaan, 5(3), 59-64.

Setyaningtyas, E. W., Guru, P., Dasar, S., Kristen, U., Wacana, S., \& Skills, C. T. (2019). Potensi Metode 1: 4: P: C: R untuk Mengembangkan Keterampilan Berpikir Kritis dan Kreatif. Scholaria: Jurnal Pendidikan Dan Kebudayaan, 9(2), 111-121.

Susilawati, E., Samsudin, A., \& Siahaan, P. (2020). Analisis Tingkat Keterampilan Berpikir Kritis Siswa SMA. Jurnal Pendidikan Fisika Dan Teknologi, 6(1), 11-16. https://doi.org/10.29303/jpft.v6i1.1453

Tresnawati, T., Hidayat, W., \& Rohaeti, E. E. (2017). Kemampuan Berpikir Kritis Matematis Dan Kepercayaan Diri Siswa SMA. Symmetry: Pasundan Journal of Research in Mathematics Learning and Education, 2(2), 116-122. https://doi.org/10.23969/symmetry.v2i2.616

Zetriuslita, Z., Ariawan, R., \& Nufus, H. (2016). Analisis Kemampuan Berpikir Kritis Matematis Mahasiswa Dalam Menyelesaikan Soal Uraian Kalkulus Integral Berdasarkan Level Kemampuan Mahasiswa. Infinity Journal, 5(1), 56. https://doi.org/10.22460/infinity.v5i1.p5666 